\title{
s-SHIP promoter expression marks activated stem cells in developing mouse mammary tissue
}

\author{
Lixia Bai ${ }^{1}$ and Larry R. Rohrschneider ${ }^{1,2,3}$ \\ ${ }^{1}$ Division of Basic Sciences, Fred Hutchinson Cancer Research Center, Seattle, Washington 98109, USA; ${ }^{2}$ Department of \\ Pathology, University of Washington, Seattle, Washington 98195, USA
}

\begin{abstract}
Mammary stem cells (MaSCs) play critical roles in normal development and perhaps tumorigenesis of the mammary gland. Using combined cell markers, adult MaSCs have been enriched in a basal cell population, but the exact identity of MaSCs remains unknown. We used the s-SHIP promoter to tag presumptive stem cells with GFP in the embryos of a transgenic mouse model. Here we show, in postnatal mammary gland development, that GFP ${ }^{+}$ cap cells in puberty and basal alveolar bud cells in pregnancy each exhibit self-renewal and regenerative capabilities for all mammary epithelial cells of a new functional mammary gland upon transplantation. Single $\mathrm{GFP}^{+}$cells can regenerate the mammary epithelial network. $\mathrm{GFP}^{+}$mammary epithelial cells are $\mathrm{p}^{+} 3^{+}, \mathrm{CD}^{\mathrm{mod}}{ }^{\mathrm{mod}}$, $\mathrm{CD} 49 \mathrm{f}^{\text {high }}$, and CD29 high, are actively proliferating; and express s-SHIP mRNA. Overall, our results identify the' activated MaSC population in vivo at the forefront of rapidly developing terminal end buds (puberty) and alveolar buds (pregnancy) in the mammary gland. In addition, GFP $^{+}$basal cells are expanded in MMTV-Wnt1 breast tumors but not in ErbB2 tumors. These results enable MaSC in situ identification and isolation via a consistent single parameter using a new mouse model with applications for further analyses of normal and potential cancer stem cells.
\end{abstract}

[Keywords: Stem cell; mammary gland development; cap cells; alveolar bud cells; s-SHIP; breast tumors]

Supplemental material is available at http://www.genesdev.org.

Received April 1, 2010; revised version accepted July 16, 2010.

The female mammary gland is a fascinating model for studying adult mammary stem cells (MaSCs), because complex stage-specific development occurs in puberty and pregnancy (Wiseman and Werb 2002; Hennighausen and Robinson 2005). After birth, only a few small rudimentary mammary ducts are present in the fat pad. At the onset of puberty, ductal elongation begins with the formation of bulb-like terminal end buds (TEBs) at the ends of primitive ducts to generate the main trunks of the mammary epithelial tree (Daniel and Silberstein 2000). Mammary epithelium is comprised of an outer layer of myoepithelial and inner luminal cells. TEBs contain outer cap cells and inner multiple layers of body cells. From morphology and immunostaining analyses, it is thought that cap cells are progenitors of myoepithelial cells, and body cells represent progenitors of luminal cells of the subtending ducts (Daniel and Silberstein 2000; Smalley and Ashworth 2003). The fact that some cap cells appear in body cell layers has led to the hypothesis that cap cells might be MaSCs (Williams and Daniel 1983;

${ }^{3}$ Corresponding author.

E-MAIL lrohrsch@fhcrc.org; FAX (206) 667-3308.

Article is online at http://www.genesdev.org/cgi/doi/10.1101/gad.1932810.
Daniel and Silberstein 2000; Smalley and Ashworth 2003; Srinivasan et al. 2003); however, no functional evidence has been presented to address this notion. In the postpubertal virgin mammary gland, dormant MaSCs are believed to be scattered throughout the epithelial ductwork (Welm et al. 2002; Smith and Medina 2008), while pregnancy lobular development starts with the generation of alveolar buds that grow and terminally differentiate into secretory alveoli to produce milk during lactation (Daniel and Silberstein 2000; Hennighausen and Robinson 2005; Deugnier et al. 2006). Following weaning, the lobulo-alveoli degrade, and the gland remodels to a virgin-like state in preparation for the next pregnancy (Smalley and Ashworth 2003; Hennighausen and Robinson 2005). Although alveolar progenitors may be committed to the alveolar cell fates (Hennighausen and Robinson 2005; Smith and Medina 2008), little is known about MaSCs at pregnancy.

The existence of MaSCs has been demonstrated by cleared mammary fat pad transplantation assays (DeOme et al. 1959; Daniel et al. 1968). MaSCs from adult virgin mouse mammary tissue have been enriched in the $\mathrm{CD} 49 \mathrm{f}^{\text {hi }}, \mathrm{CD} 29^{\text {hi }}, \mathrm{CD} 24^{+/ \mathrm{mod}}$, and Sca- ${ }^{-/ \text {low }}$ subset of basal mammary epithelial cells (Shackleton et al. 2006; 
Sleeman et al. 2006; Stingl et al. 2006; Lindeman et al. 2008), which are negative for steroid hormone receptors (Asselin-Labat et al. 2006; Sleeman et al. 2007). However, the precise identity of adult MaSCs remains a fundamental question.

The product of the novel s-ship gene was initially identified in embryonic and hematopoietic stem cells, but not in differentiated cells (Tu et al. 2001). We therefore generated a transgenic mouse model (Tg11.5kb-GFP), and found that the $11.5-\mathrm{kb}$ s-SHIP promoter specifically expressed GFP in many stem cell populations, including mammary bud cells, in embryonic development (Rohrschneider et al. 2005). Here we show (Supplemental Fig. 1A) in the postnatal mammary gland that GFP labels puberty cap cells and pregnancy basal alveolar bud cells, and both in vivo and in vitro experiments demonstrate they are activated MaSCs. Similar $\mathrm{GFP}^{+}$cells are expressed in MMTV-Wnt1 but not ErbB2 mammary tumors. Identification of exact stem cell types and their in situ localization is an essential step toward understanding and using stem cells in medical applications.

\section{Results}

GFP is expressed in cap cells at puberty

At the beginning of puberty (4 wk of age), GFP expression was detected in TEBs at the distal tips of the growing ducts (Fig. 1A,B). The majority of $\mathrm{GFP}^{+}$cells were located in the peripheral cap cell layer, and a minor population (16\%-18\% of total $\mathrm{GFP}^{+}$cells; $\left.n=20 \mathrm{TEBs}\right)$ was seen within the inner body cell compartment of the TEBs (Fig.
1C). During ductal elongation, GFP expression remained in the cap cells, but was not detectable in epithelial cells of mature ducts (Fig. 1C; Supplemental Fig. 1C). GFP expression was present neither before puberty in the primitive ducts measured in tissue sections and flow cytometry (Supplemental Figs. 1B, 6C), nor after puberty in the mature ducts (Supplemental Figs. 1D, 6B). Throughout mammary development, a distinct GFP expression pattern was observed in angiogenic blood vessels (Fig. 1B), which we are studying separately. These findings indicate that the 11.5-kb s-SHIP promoter drives GFP expression specifically in cap cells in the mammary gland of puberty Tg11.5kb-GFP female mice. Because cap cells are the putative stem cells (Williams and Daniel 1983; Srinivasan et al. 2003), we characterized these $\mathrm{GFP}^{+}$cells in more detail.

$\mathrm{GFP}^{+}$cap cells expressed basal/myoepithelial cell markers, including p63 (Fig. 1D) (which is essential for mammary gland development [Mills et al. 1999; Yang et al. 1999] and epithelial stem cell proliferation [Senoo et al. 2007]), $\alpha$-smooth muscle actin (SMA) (Fig. 1E), low levels of Keratin 14 (K14), and basement membrane component laminin (Supplemental Fig. 2A,B). GFP ${ }^{+}$cells were negative for E-cadherin (E-cad), progesterone receptor (PR), and keratin 8 (K8) (Supplemental Fig. 2C-E)markers prevalent in body/luminal cells (Srinivasan et al. 2003; Asselin-Labat et al. 2006). K8 staining of the body cells was similar to E-cad staining with $\mathrm{GFP}^{+}$cells surrounded by $\mathrm{K}^{+}$and E-cad ${ }^{+}$body cells. (Supplemental Fig. 2E). GFP ${ }^{+}$cells in the body cell layers shared common markers with those in the outer cap cell layer, supporting previous views that some cap cells migrate into the body
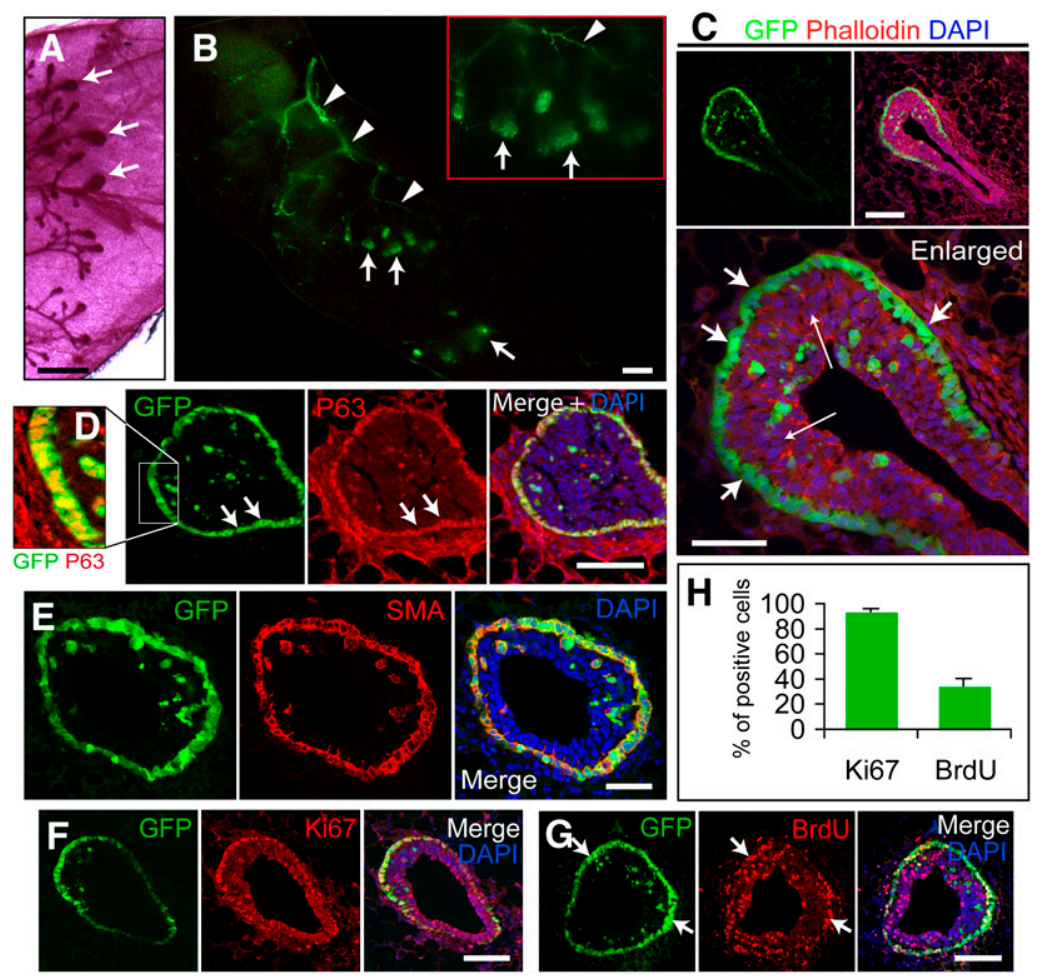

Figure 1. GFP expression occurs in cap cells of the TEBs at puberty. (A) TEBs (arrows) in carmine whole-mount-stained 5-wk mammary tissue. $(B)$ $\mathrm{GFP}^{+}$TEBs (green, arrows) and blood vessels (green, arrowheads) in 4-wk transgenic whole-mount mammary tissue. $(C)$ One section of a 4-wk TEB. Cap cells are $\mathrm{GFP}^{+}$(short arrows), and some $\mathrm{GFP}^{+}$cap cells are among the $\mathrm{GFP}^{-}$body cells (long arrows). (Red) Phalloidin-Alexa 594; (blue) DAPI. (D) $\mathrm{GFP}^{+}$ cap cells (green) are also ${\mathrm{p} 63^{+}}^{+}(\mathrm{red})$; shown in enlargement (left panel; GFP and p63 only), and separately (middle two panels). Arrows mark the cap cell layer. (E) Cap cells (green) are $\mathrm{SMA}^{+}(\mathrm{red})$. (F) Most $\mathrm{GFP}^{+}$cap cells are $\mathrm{Ki}^{+} 7^{+}$(red). (G) Some $\mathrm{GFP}^{+}$cap cells were labeled with $\mathrm{BrdU}$ (red) within $4 \mathrm{~h}$ of BrdU injection. Bars: $A, B, 1 \mathrm{~mm} ; C, D, F, G$, $100 \mu \mathrm{m} ; C$ (enlarged), $E, 50 \mu \mathrm{m}$. (H) Histogram shows that $93.8 \% \pm 2.4 \%$ of $\mathrm{GFP}^{+}$cells in TEBs are $\mathrm{Ki}^{+} 7^{+}$, and $34.6 \% \pm 5.9 \%$ of $\mathrm{GFP}^{+}$cells were labeled with BrdU during a 4-h exposure. Data represent mean $\pm S D ; n=20$ TEBs. 
cell compartment (Williams and Daniel 1983; Daniel and Silberstein 2000). $\mathrm{GFP}^{+}$cells were $93.8 \% \pm 2.4 \% \quad(n=20$ TEBs) positive for proliferation marker Ki67 (Fig. 1F,H), and $34.6 \% \pm 5.9 \%(n=20$ TEBs $)$ positive for 5-bromo2 '-deoxyuridine (BrdU) within $4 \mathrm{~h}$ of labeling (Fig. 1G,H). Many body cells in TEBs were also $\mathrm{Ki}^{+} 7^{+}$and $\mathrm{BrdU}^{+}$(Fig. $1 F, G)$. These data indicate that $\mathrm{GFP}^{+}$cap cells exhibit a basal cell phenotype and are actively dividing.

We next examined $\mathrm{GFP}^{+}$cap cells for markers historically associated with stem/progenitor cells in various tissues. Using the integrin $\alpha_{6} /$ CD49f marker of stem cells (Iwashita et al. 2003; Stingl et al. 2006; Lawson et al. 2007), we first determined that $\mathrm{GFP}^{+}$cap cells (CD49f $\mathrm{f}^{\text {high }}$ ) were separable from $\mathrm{GFP}^{+}$vascular cells $\left(\mathrm{CD} 49 \mathrm{f}^{-/ \mathrm{low}}\right.$ ) (Supplemental Fig. 3A,B). Analyzing lin ${ }^{-}$mammary cells (excluding CD $31^{+}$endothelial and CD $45^{+}$TER $119^{+}$hematopoietic cells) from puberty and prepuberty by flow cytometry, we then identified and isolated $\mathrm{GFP}^{+}$cap cells as the distinct $\mathrm{GFP}^{+} \mathrm{CD} 49 \mathrm{f}^{\text {high }}$ population, whereas the $\mathrm{GFP}^{+} \mathrm{CD} 49 \mathrm{f}^{-/ \text {low }}$ cell group corresponded to the $\mathrm{GFP}^{+}$ vascular cells (Supplemental Fig. 3C-E). GFP ${ }^{+}$cap cells accounted for $2 \%-6 \%$ of lin $^{-}$mammary cells in puberty glands (Fig. 2A). GFP $^{+}$cap cells were CD29 ${ }^{\text {high }}$ (integrin $\beta_{1}$, a stem cell marker in skin [Jones et al. 1995] and mammary gland [Shackleton et al. 2006]) (Fig. 2B); Sca-1 $1^{-/ \text {low }}$ (Fig. 2C); negative for prominin1/CD133 (Fig. 2D), a potential cancer stem cell marker (Singh et al. 2004; Zhu et al. 2009); and positive for integrin $\beta_{3} /$ CD61 (Fig. 2E), expressed in mammary stem/progenitor cells (AsselinLabat et al. 2007). GFP ${ }^{+}$cells were not in the side population (Fig. 2F) used to enrich mammary progenitors (Welm et al. 2002; Liu et al. 2004).

To examine whether $\mathrm{GFP}^{+}$cells express s-SHIP, RTPCR was performed on sorted $\mathrm{GFP}^{+}$and $\mathrm{GFP}^{-}$cells. The results demonstrate that the s-SHIP promoter-driven GFP expression correlates with the endogenous s-SHIP mRNA expression (Fig. 2G). To determine the in vitro growth and differentiation potential of $\mathrm{GFP}^{+}$cap cells, $\mathrm{GFP}^{+} \mathrm{CD} 49 \mathrm{f}^{\text {high }}$ and $\mathrm{GFP}^{-}$cells were sorted from the lin population and cultured in Matrigel for $12 \mathrm{~d}$. Single lin $^{-} \mathrm{GFP}^{+} \mathrm{CD} 49 \mathrm{f}^{\text {high }}$ cells were able to generate colonies, and $\sim 10 \%-15 \%$ of the colonies expressed GFP (Fig. $2 \mathrm{H}, \mathrm{I}$ ). In most of the $\mathrm{GFP}^{+}$colonies, only a subfraction of cells were $\mathrm{GFP}^{+}$, as shown in Figure 2, H and I. K14 was strongly expressed in the outer layer of cells, but was not expressed in the inner layer of cells of the colonies (Fig. 2J). Compared with lin $^{-} \mathrm{GFP}^{-}$cells, lin $^{-} \mathrm{GFP}^{+} \mathrm{CD} 49 \mathrm{f}^{\text {high }}$ cells exhibited a fivefold higher colony-forming ability in Matrigel (42.0 \pm 4.2 vs. $211.2 \pm 21.0$ colonies per 1000 cells; mean $\pm \mathrm{SD} ; P<0.0001$ ) (Fig. $2 \mathrm{~K}$ ).

\section{Multipotential and self-renewal capability of $G F P^{+}$ cap cells}

To determine whether $\mathrm{GFP}^{+}$cap cells can regenerate new mammary gland epithelial tissue, freshly sorted lin $^{-} \mathrm{GFP}^{+} \mathrm{CD} 49 \mathrm{f}^{\text {high }}$ cells (Supplemental Fig. 3C,D) were transplanted at various dilutions into cleared fat pads of 3-wk-old wild-type C57BL/6J female mice. $\mathrm{Lin}^{-} \mathrm{GFP}^{-}$ cells were collected from the same tissues and transplanted as a control. Donor cells were harvested from Tg11.5kb-GFP mice or bitransgenic Tg11.5kb-GFP;Rosa26 mice, allowing confirmation of donor origin by staining for constitutive lacZ expression (Friedrich and Soriano 1991). Results of transplantation experiments (Supplemental Table 1A) showed that $\mathrm{GFP}^{+}$cap cells displayed much higher regenerative ability (10 outgrowths out of 10 injected fat pads when 400 cells were injected), compared with $\mathrm{GFP}^{-}$cells (one out of 10; 400 cells injected); injection of $200 \mathrm{GFP}^{+}$cells repopulated 11 out of 12 fat
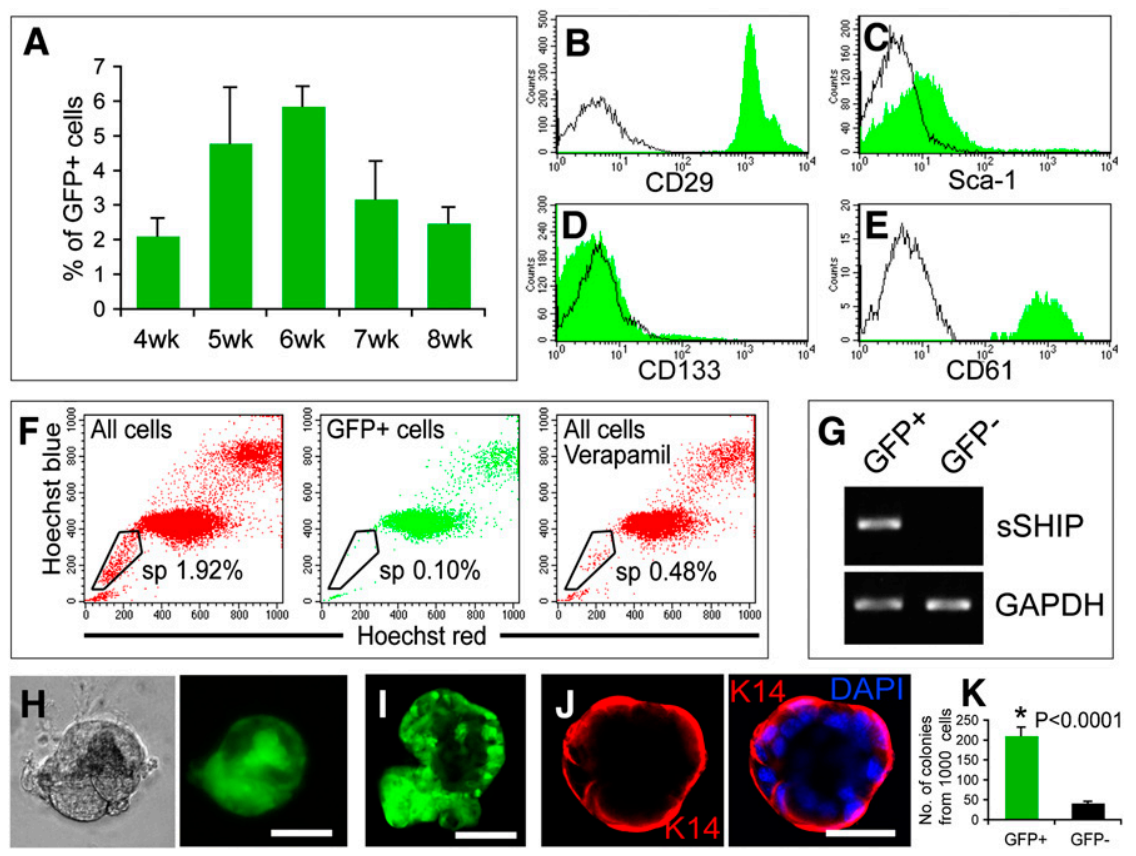

Figure 2. Characterization of $\mathrm{GFP}^{+}$cap cells in puberty. (A) Histogram shows the percentage of $\operatorname{lin}^{-} \mathrm{GFP}^{+} \mathrm{CD} 49 \mathrm{f}^{\text {high }}$ cap cells in total lin ${ }^{-}$puberty mammary cells. Results represent mean \pm SD of four mice for each group. $(B-E)$ Flow cytometric analysis shows that $\mathrm{GFP}^{+} \mathrm{CD} 49 \mathrm{f}^{\text {high }}$ cap cells are CD29 ${ }^{\text {high }}(B)$, Sca-1 ${ }^{-/ \text {low }}(C), \mathrm{CD}_{133^{-}}(D)$, and $\mathrm{CD}^{+} 1^{+}(E) .(F)$ Side population analysis shows that puberty $\mathrm{GFP}^{+}$cells are depleted in the side population. (G) RT-PCR shows s-SHIP mRNA in sorted $\mathrm{GFP}^{+}$cells but not in $\mathrm{GFP}^{-}$cells. $(H, I)$ Single $\mathrm{GFP}^{+} \mathrm{CD} 49 \mathrm{f}^{\text {high }}$ cap cells form alveolar-like colonies in Matrigel; photographed with a Nikon microscope in situ in Martrigel (phase and GFP) $(H)$, or removed from Matrigel and examined for GFP by confocal microscopy $(I)$. $(J) \mathrm{K} 14^{+}$cells (red) comprise the outer layer of the colony (DAPI-stained for nuclei; blue). Bars: $H, J, 20 \mu \mathrm{m} ; I, 50 \mathrm{~mm} .(K)$ Histogram shows the colony-forming capacity of lin $^{-} \mathrm{GFP}^{+} \mathrm{CD} 49 \mathrm{f}^{\text {high }}$ and lin $^{-} \mathrm{GFP}^{-}$ cells in Matrigel. Data represent mean \pm $\mathrm{SD}$ of five independent experiments. 
pads, while $\mathrm{GFP}^{-}$cells were unable to produce an outgrowth. Limiting dilution analysis (Shackleton et al. 2006) indicated that the frequency of MaSCs in the GFP ${ }^{+}$ population was one out of 48 , compared with one out of 7570 in $\mathrm{GFP}^{-}$cells $(P<0.0001)$. Since low numbers of $\mathrm{GFP}^{+}$cells (three to eight cells) could regenerate outgrowths (Supplemental Table 1A), we performed single $\mathrm{GFP}^{+}$cell transplantation and obtained two outgrowths from 28 transplants (Supplemental Table 1B).

The frequency of MaSCs in lin $^{-}$unfractionated cells was one out of 3523 (Supplemental Table 2). Regenerative activity was present in $\mathrm{GFP}^{+} \mathrm{CD} 49 \mathrm{f}^{\text {high }}$ cap cells, but not in the $\mathrm{GFP}^{+} \mathrm{CD} 49 \mathrm{f}^{-/ \text {low }}$ vascular cells (Supplemental Fig. 4).

We next investigated the ability of $\mathrm{GFP}^{+}$cells to form cells and structures of the outgrowths in puberty. Outgrowths from $\mathrm{GFP}^{+}$cap cells (recipients in puberty) exhibited GFP expression in TEBs as observed in Tg11.5kb-GFP females, except the outgrowth pattern radiated from the injection site (Fig. 3A). An outgrowth from three to eight $\mathrm{GFP}^{+}$cells and from one single cell are shown in Figure $3 \mathrm{~B}$ and its inset, respectively. Outgrow ths from approximately eight $\mathrm{GFP}^{+} \mathrm{LacZ}^{+}$cells could be transplanted serially, and regenerated outgrowths with TEBs at the tips of ducts in virgin recipients (Fig. 3C). TEBs in the $\mathrm{GFP}^{+}$cap cell-derived outgrowths were composed of $\mathrm{GFP}^{+} \mathrm{SMA}^{+}$cap cells (Fig. 3D) and E-cad ${ }^{+}$ body cells (Fig. 3E). Recipient mice bred for pregnancy exhibited typical outgrowths $\left(\mathrm{GFP}^{+} \mathrm{LacZ}^{+}\right.$cell-derived) at pregnancy and early lactation stages (Fig. 3F,G). Milk protein was apparent inside alveolar lumen (Fig. $3 \mathrm{H}$ ). Outgrowth lobulo-alveoli were composed of $\mathrm{SMA}^{+}$ myoepithelial cells and E-cad ${ }^{+}$alveolar luminal cells (Fig. 3I). Flow cytometric analysis showed that $\mathrm{GFP}^{+}$cells in the outgrowths were CD49f $\mathrm{f}^{\text {high }}$ and CD24 ${ }^{\mathrm{mod}}$, and were present in relative numbers comparable with those seen in Tg11.5kb-GFP female mice (Supplemental Fig. 5). These results indicated that $\mathrm{GFP}^{+}$cap cells give rise to all structures and cell lineages of the new mammary gland in puberty and pregnancy.

Interestingly, the few outgrowths obtained from GFP cells also exhibited $\mathrm{GFP}^{+}$cap cells in TEBs /data not shown), suggesting the existence of $\mathrm{GFP}^{-}$dormant MaSCs, which turn on GFP expression upon activation. We tested the possibility that $\mathrm{GFP}^{+}$cells were contained in the $\mathrm{GFP}^{-}$population by resorting $\mathrm{GFP}^{-}$cells freshly isolated by FACS. The results in Supplemental Figure 6A demonstrate that $\mathrm{GFP}^{+}$cells were not detectable in $10^{4}$ sorted $\mathrm{GFP}^{-}$cells. Derivation of $\mathrm{GFP}^{+}$outgrowths from $\mathrm{GFP}^{-}$cells was further confirmed by transplantation of lin ${ }^{-} \mathrm{CD} 24^{+} \mathrm{CD} 49 \mathrm{f}^{\text {hi }} \mathrm{GFP}^{-}$mammary cells from adult virgin mice (Supplemental Fig. 6B). This indicates that $\mathrm{GFP}^{-}$ cells transplanted into cleared fat pads must have turned on GFP expression in forming an epithelial outgrowth.

To assess the self-renewal ability of $\mathrm{GFP}^{+}$cap cells, serial transplantations of 100 and approximately eight $\mathrm{GFP}^{+}$cap cells were performed. Supplemental Table 1C shows that all injected fat pads were repopulated with epithelial outgrowths in the second, third, and fourth serial transplants. These data demonstrate that $\mathrm{GFP}^{+}$cap cells possess not only the activity of regeneration and differentiation, but also the capacity of self-renewal.

\section{$G_{F P}^{+}$cells in alveolar buds at pregnancy}

After puberty, GFP expression was not detected in mammary epithelial cells of adult virgin transgenic mice

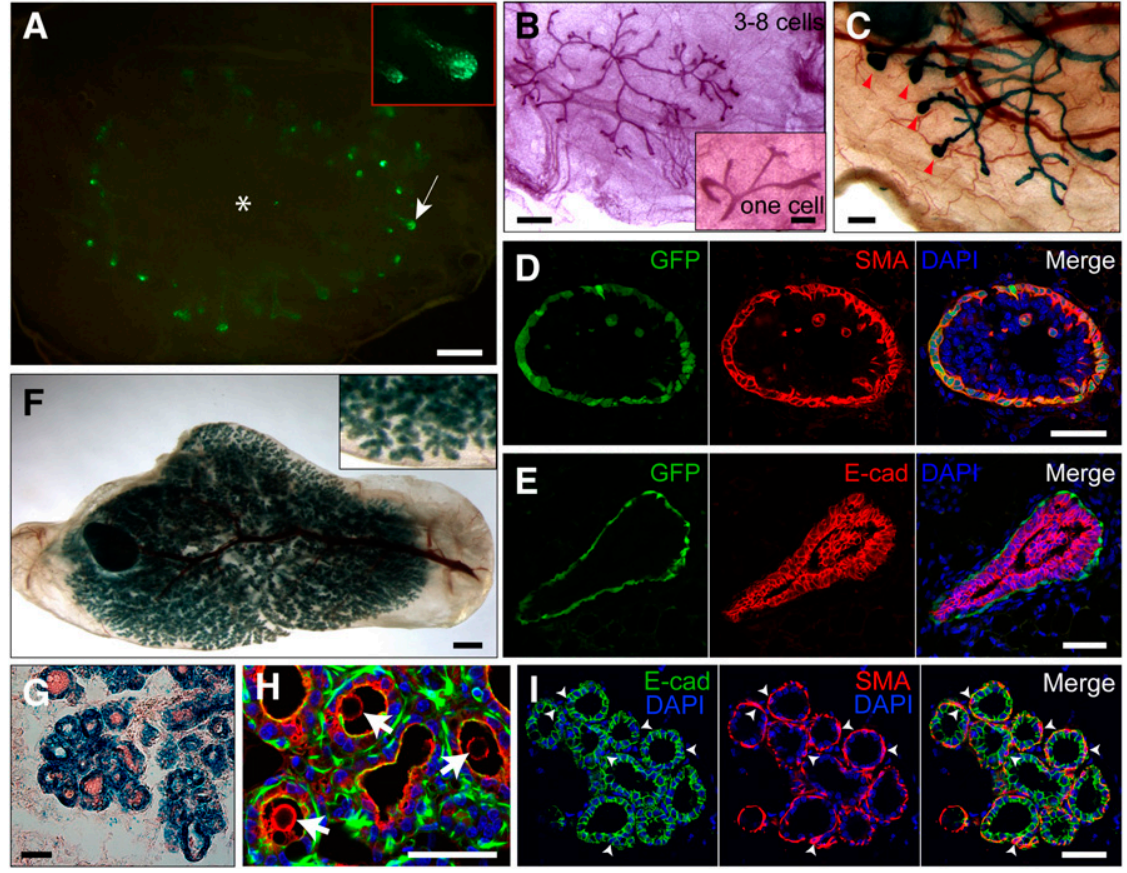

Figure 3. Characterization of transplantation outgrowths from puberty $\mathrm{GFP}^{+}$cap cells. (A) $\mathrm{GFP}^{+}$TEBs (green, arrow) in an outgrowth from $40 \mathrm{GFP}^{+}$cap cells; enlarged TEBs are shown in the inset. $\left({ }^{*}\right)$ Approximate injection site. (B) Carmine alumstained ductal outgrowths from four (three to eight) cells, or one single $\mathrm{GFP}^{+}$cap cell (inset), respectively. $(C) \mathrm{X}$-gal staining shows the TEBs (arrowheads) in a second serial outgrowth originated from eight (six to 10) primary $\mathrm{GFP}^{+} \mathrm{LacZ}^{+}$cap cells. $(D, E)$ Outgrowth TEBs consist of $\mathrm{GFP}^{+} \mathrm{SMA}^{+}$cap cells $(D)$ and E-cad ${ }^{+}$body cells $(E) .(F-I)$ Pregnancy-induced lobulo-alveolar formation in lactating outgrowths (lactation day 0.5 ) derived from $40 \mathrm{GFP}^{+} \mathrm{LacZ}^{+}$cap cells. $(F)$ X-gal whole-mount staining shows lobulo-alveolar structures of outgrowth. (G) Frozen section of outgrowth lobuloalveoli stained with X-gal (blue) and nuclear fast red (red). (H) Antibody staining for milk protein (arrows) in alveolar lumen. (Red) Milk; (green) phalloidin; (blue) DAPI. (I) Outgrowth lobulo-alveoli are composed of $\mathrm{SMA}^{+}$myoepithelial cells (arrowheads) and E-cad ${ }^{+}$alveolar luminal cells. Bars: $A, B, F$, $1 \mathrm{~mm} ; B$ (inset), $C, 0.25 \mathrm{~mm} ; D, E, G-I, 50 \mu \mathrm{m}$. 
examined in tissue sections and flow cytometry (Supplemental Figs. 1D, 6B). However, in pregnancy, GFP expression was observed in apparent alveolar buds along the ductal network (Fig. 4A,B), and was restricted mainly to the outer layer of cells and the tips of alveolar buds (Fig. $4 \mathrm{C}, \mathrm{D})$. A few $\mathrm{GFP}^{+}$cells were also present in the luminal cell layers (Fig. 4D). Expression of GFP was detected in the alveolar buds as early as pregnancy day 2.5 (P2.5) (Fig. 4E) and was retained until P15.5, when GFP turned off in all mammary epithelial cells for the duration of late pregnancy. Expression was seen in neither terminally differentiated lobulo-alveolar cells at P17.5, nor lactation, nor involution stages of mammary tissues (Supplemental Fig. 1E-G).

Pregnancy $\mathrm{GFP}^{+}$epithelial cells were $\mathrm{SMA}^{+}$(Fig. 4E), $\mathrm{p} 3^{+}$, laminin $^{+}, \mathrm{K} 14^{\text {low }}, \mathrm{CD} 49 \mathrm{f}^{\text {high }}$, and E-cad ${ }^{-}$(Supplemental Fig. 7A-E). Most GFP ${ }^{+}$cells $(91.5 \% \pm 5.9 \% ; n=20$ alveolar buds) were stained with $\mathrm{Ki67}$ (Fig. 4F,G), and $27.7 \% \pm 10.9 \%$ ( $n=20$ alveolar buds) of $\mathrm{GFP}^{+}$cells were labeled with BrdU within $4 \mathrm{~h}$ (Fig. 4G; Supplemental Fig. $7 F)$, suggesting these cells are highly proliferative. $\mathrm{GFP}^{+} \mathrm{CD} 49 \mathrm{f}^{\text {high }}$ alveolar bud cells from early pregnancy comprised $\sim 2 \%$ of the $\operatorname{lin}^{-}$population, and the number increased to $\sim 9.5 \%$ in midpregnancy (Fig. $4 \mathrm{H}, \mathrm{I}$ ). Pregnancy $\mathrm{GFP}^{+} \mathrm{CD} 49$ f $^{\text {high }}$ cells were CD2 $4^{\text {mod }}$ (Supplemental Fig. 8), CD29 $9^{\text {high }}$, Sca- $1^{-/ \text {low }}, \mathrm{CD}_{133^{-}}$, and CD61 $1^{+}$, and not side population cells (Supplemental Fig. 9A-E). s-SHIP mRNA was expressed only in $\mathrm{GFP}^{+}$cells (Supplemental Fig. 9F). Single pregnancy $\mathrm{GFP}^{+}$cells in Matrigel formed alveolar-like colonies, composed of an outer layer of integrin $\alpha_{6}{ }^{+}$and inner integrin $\alpha_{6}{ }^{-}$cells. $\mathrm{GFP}^{+}$cells showed a more than threefold higher colony-forming ability than $\mathrm{GFP}^{-}$cells $(194.2 \pm 15.5$ vs. $52.6 \pm 4.0$ colonies per 1000 cells; mean \pm SD; $P<0.0001$ ) (Supplemental Fig. 9G-I).

Taken together, $\mathrm{GFP}^{+}$alveolar bud cells in pregnancy displayed properties similar to $\mathrm{GFP}^{+}$cap cells in puberty.

\section{$\mathrm{GFP}^{+}$alveolar bud cells possess MaSC activity}

Limiting dilution studies showed that $\mathrm{GFP}^{+}$alveolar bud cells exhibited marked regenerative capacity, and low numbers of cells (four to six cells) could reconstitute the ductal network (Supplemental Table 3A; Supplemental Fig. 10A). The frequency of MaSCs in pregnancy $\mathrm{GFP}^{+}$ cells was one out of 79, compared with one out of 1948 in $\mathrm{GFP}^{-}$cells $(\mathrm{P}<0.0001)$ (Supplemental Table $\left.3 \mathrm{~A}\right)$, and one out of 1750 in lin $^{-}$unfractionated cells (Supplemental Table 4), indicating that MaSCs are much more abundant in the $\mathrm{GFP}^{+}$population compared with $\mathrm{GFP}^{-}$(24-fold) or unfractionated cells (22-fold).

Transplanted into pubertal fat pads, pregnancy $\mathrm{GFP}^{+}$ cells regenerated ductal epithelial trees with TEBs, which expressed GFP (Fig. 4J,K). Outgrowth TEBs contained $\mathrm{GFP}^{+} \mathrm{SMA}^{+}$cap cells and E-cad ${ }^{+}$body cells (Supplemental Fig. 10B,C). Lobulo-alveoli were formed in lactating outgrowths derived from $\mathrm{GFP}^{+} l a c Z^{+}$pregnancy cells (Supplemental Fig. 10D-G), and alveoli produced milk (Supplemental Fig. 10H). Outgrowth alveoli consisted of $\mathrm{SMA}^{+}$myoepithelial cells and E-cad ${ }^{+}$alveolar luminal cells (Supplemental Fig. 10I). These data demonstrate that pregnancy $\mathrm{GFP}^{+}$cells can regenerate a fully functional mammary gland and contribute to all cell types during puberty and pregnancy development. Finally, serial transplantation indicated complete capabilities for self-renewal of $\mathrm{GFP}^{+}$alveolar bud cells (Supplemental Table 3B).
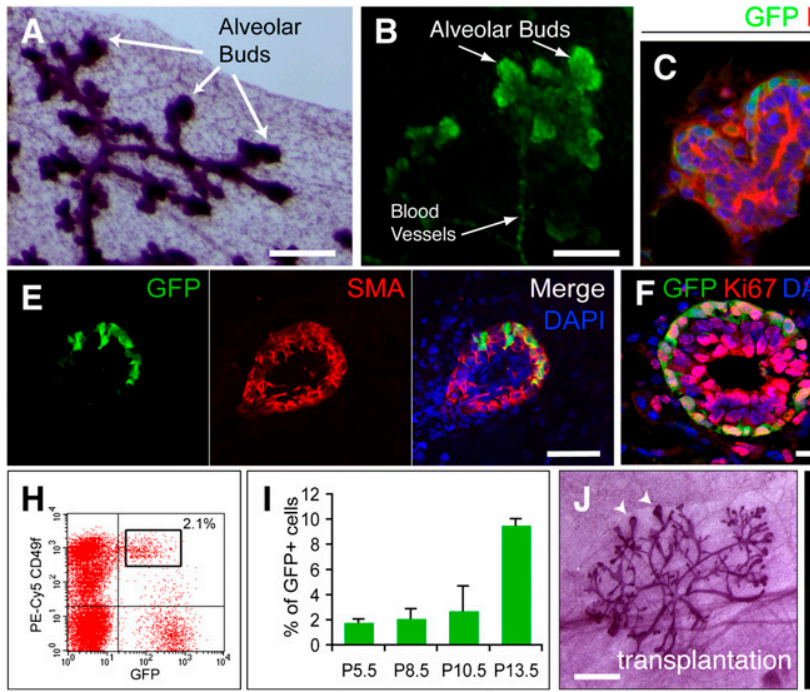

GFP Phalloidin DAPI

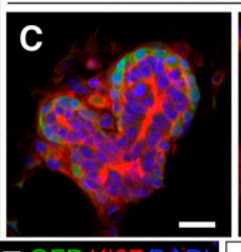

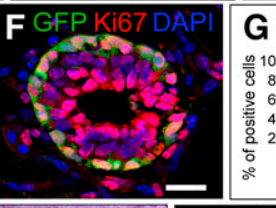

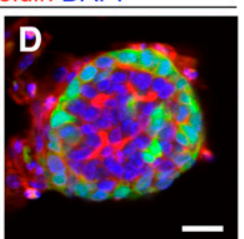

G

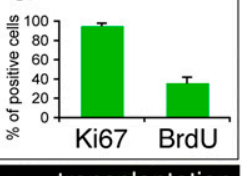

$\mathbf{K}$
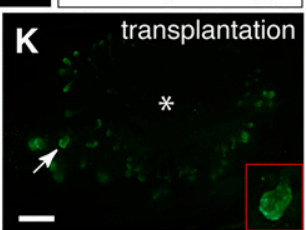

Figure 4. Identification and characterization of $\mathrm{GFP}^{+}$cells in alveolar buds at pregnancy. $(A-D)$ Alveolar buds in P11.5 transgenic mammary tissues. Carmine whole-mount staining shows alveolar buds along the ductal network $(A)$, GFP expression (green) in the apical alveolar buds, and some blood vessels $(B)$. Frozen sections show that GFP is expressed mainly in the peripheral cells, especially the tips of the alveolar buds $(C, D)$, and some $\mathrm{GFP}^{+}$cells are seen in the inner layer of the alveolar buds $(D)$. $(E) \mathrm{GFP}^{+}$ cells in P2.5 mammary tissue are $\mathrm{SMA}^{+}$ (red). (F) Most $\mathrm{GFP}^{+}$cells in P7.5 alveolar bud are $\mathrm{Ki}^{+}$(red). $(G)$ Histogram shows that $91.5 \% \pm 5.9 \%$ of $\mathrm{GFP}^{+}$cells at pregnancy are $\mathrm{Ki} 67^{+}$, and $27.7 \% \pm 10.9 \%$ of $\mathrm{GFP}^{+}$cells were labeled with BrdU within $4 \mathrm{~h}$ of injection. Data represent mean $\pm \mathrm{SD}$; $n=20$ alveolar buds. $(H)$ Flow cytometric analysis of lin $^{-}$mammary cells from P5.5 mammary tissues. GFP ${ }^{+}$cells consist of CD49f $\mathrm{f}^{\text {high }}$ alveolar bud cells (gate) and CD49f ${ }^{-/ \text {low }}$ blood vessel cells. (I) Histogram shows the percentage of $\mathrm{GFP}^{+} \mathrm{CD} 49 \mathrm{f}^{\text {high }}$ alveolar bud cells in the total lin $^{-}$population during pregnancy. Results represent mean $\pm \mathrm{SD}$ of four mice for each group. $(J)$ Carmine alum staining of an outgrowth from 100 pregnancy $\mathrm{GFP}^{+}$cells shows the TEBs (arrowheads) at the ductal ends. (K) GFP ${ }^{+}$TEBs in the outgrowth of 50 pregnancy $\mathrm{GFP}^{+}$cells. ( ${ }^{\star}$ ) Approximate injection site. Bars: $A, B, 200 \mu \mathrm{m} ; C, D, F, 20 \mu \mathrm{m}$; E, $50 \mu \mathrm{m} ; J, K, 1 \mathrm{~mm}$. 
Direct comparison of $\mathrm{GFP}^{+}$MaSCs with isolates characterized previously

The $\mathrm{GFP}^{+}$cap cell population was compared directly with the MaSCs isolated by the Eaves (Stingl et al. 2006) and Visvader (Shackleton et al. 2006) groups. In each case, the results (Fig. 5A,B) demonstrate that our lin $^{-} \mathrm{GFP}^{+} \mathrm{CD}_{49 \mathrm{f}^{+}}$mammary cap cell fraction represents a precise subpopulation of the MaSCs identified with Lin $^{-}$CD $24^{\text {mod }}$ CD $49 f^{\text {high }}$ and $\operatorname{lin}^{-} \mathrm{CD} 24^{\text {mod }}$ CD29 ${ }^{\text {high }}$ phenotypes from the respective laboratories. In puberty, the $\mathrm{GFP}^{+}$fraction comprised $9 \%$ of the former population and $22 \%$ of the latter. GFP expression is not yet known to occur in the virgin phase of mammary development, and therefore a full comparison cannot be made between the $\mathrm{GFP}^{+}$cells and those of the other groups, which obtained MaSCs from virgin epithelial ducts. In addition, the colony-forming capability of $\operatorname{lin}^{-} \mathrm{CD} 24^{+} \mathrm{CD} 49 \mathrm{f}^{\text {high }} \mathrm{GFP}^{+}$cells was also significantly higher than that of 1 in $^{-} \mathrm{CD} 24^{+} \mathrm{CD} 49 \mathrm{f}^{\text {high }} \mathrm{GFP}^{-}$cells $(P=0.0003)$ (Fig. 5C). The characteristics of $\mathrm{GFP}^{+}$ mammary epithelial cells are consistent with the phenotype and stem cell nature of mammary epithelial cell fractions isolated by others, but represents a subfraction of the MaSCs isolated by multiple parameters in other laboratories.

We also examined transplantations of $\operatorname{lin}^{-} \mathrm{GFP}^{+}$mammary epithelial cells contained within CD49fhigh and CD24 ${ }^{+}$fractions (Shackleton et al. 2006; Sleeman et al. 2006; Stingl et al. 2006). These experiment showed that $\operatorname{lin}^{-} \mathrm{CD} 24^{+} \mathrm{CD} 49 \mathrm{f}^{\text {high }} \mathrm{GFP}^{+}$cap cells possessed a significantly higher regenerative potential than $\operatorname{lin}^{-} \mathrm{CD} 24^{+} \mathrm{CD} 49 \mathrm{f}^{\text {high }} \mathrm{GFP}^{-}$cells (one out of 71 vs. one out of 333 MaSC frequency; $P=0.003$ ) (Fig. 5C).
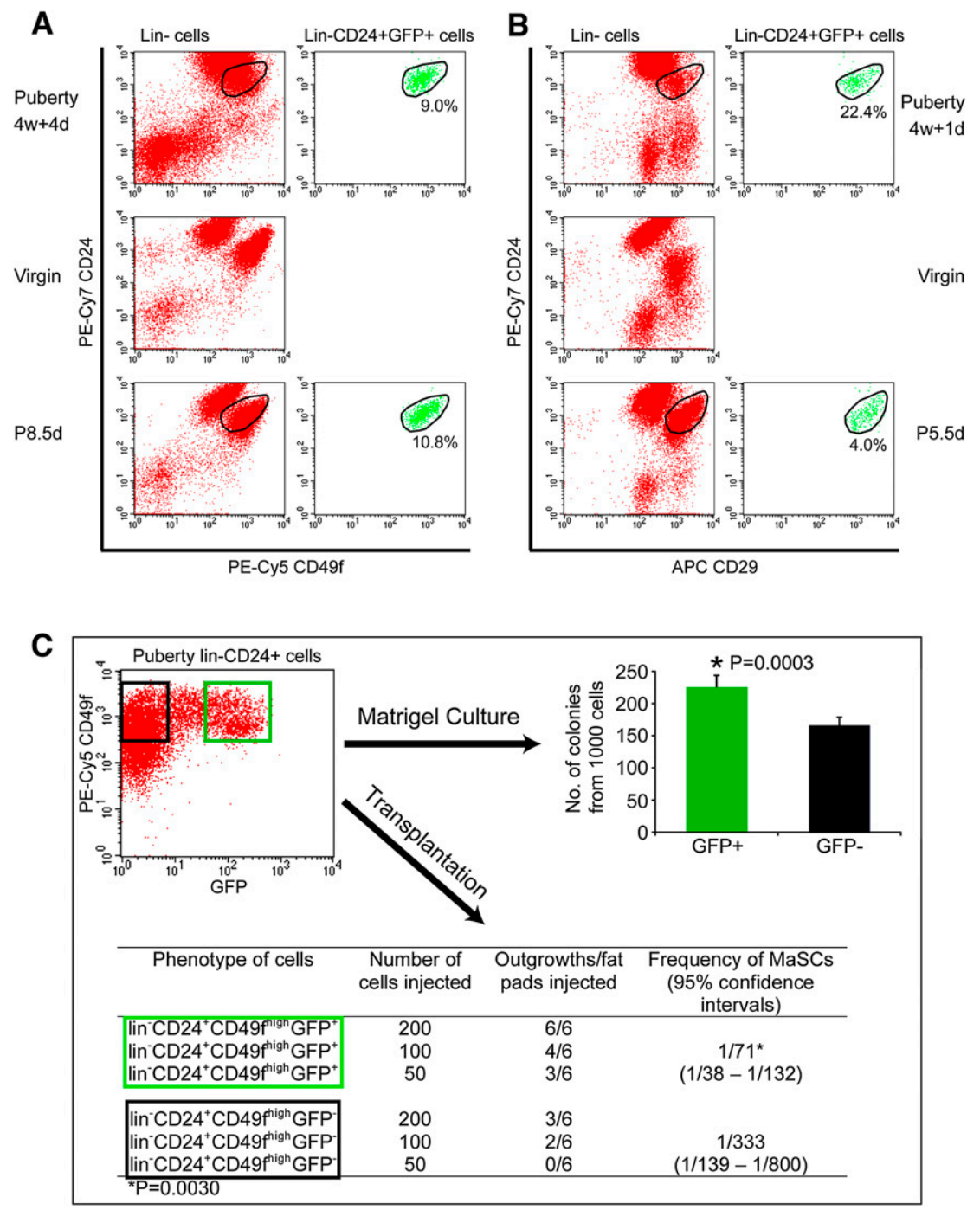

Figure 5. Comparison of $\mathrm{GFP}^{+}$mammary epithelial cells with previously identified $\operatorname{lin}^{-} \mathrm{CD} 24^{\mathrm{mod}} \mathrm{CD} 49 \mathrm{f}^{\text {high }}$ and $\operatorname{lin}^{-} \mathrm{CD} 24^{\mathrm{mod}}$ CD29 ${ }^{\text {high }}$ MaSC phenotypes. (A) Mammary cells from puberty $(4 \mathrm{w}+4 \mathrm{~d})$, adult virgin $(6 \mathrm{~m})$, and pregnancy $(\mathrm{P} 8.5 \mathrm{~d}, 6 \mathrm{~m})$ were stained and analyzed simultaneously. The left panels show that the distributions of lin ${ }^{-}$mammary cells from different developmental stages based on CD24 and CD49f expression level are quite different. Unlike in virgin mammary cells, there are no clearly distinguishable $\mathrm{CD} 24^{\text {high }} \mathrm{CD} 49 \mathrm{f}^{\text {low }}$ and $\mathrm{CD} 24^{\text {mod }} \mathrm{CD} 49 \mathrm{f}^{\text {high }}$ populations in puberty $(4 w+4 d)$ lin $^{-}$mammary cells. The right panels show that $\mathrm{GFP}^{+}$epithelial cells account for $9.0 \%$ and $10.8 \%$ of the overlapped lin $^{-} \mathrm{CD} 24^{\mathrm{mod}} \mathrm{CD} 49 \mathrm{f}^{\text {high }}$ cells in puberty $(4 \mathrm{w}+4 \mathrm{~d})$ and in pregnancy $(\mathrm{P} 8.5 \mathrm{~d})$, respectively. $\operatorname{Lin}^{-} \mathrm{CD} 24{ }^{\text {mod }} \mathrm{CD} 49 \mathrm{f}^{\text {high }} \mathrm{GFP}^{+}$ cells are not present in virgin transgenic mammary cells. (B) Mammary cells from puberty $(4 \mathrm{w}+1 \mathrm{~d})$, adult virgin $(6 \mathrm{~m})$, and pregnancy $(\mathrm{P} 8.5 \mathrm{~d}, 6 \mathrm{~m})$ were stained and analyzed simultaneously. The left panels show the differences among the distribution of lin $^{-}$mammary cells from different stages according to CD24 and CD29 expression. Clearly distinguishable $\mathrm{CD} 24^{\text {high }} \mathrm{CD} 29^{\text {low }}$ and $\mathrm{CD} 24^{\mathrm{mod}} \mathrm{CD} 29^{\text {high }}$ populations do not exist in puberty $(4 \mathrm{w}+4 \mathrm{~d})$ lin $^{-}$mammary cells. The right panels show that $\mathrm{GFP}^{+}$epithelial cells represent $22.4 \%$ and $4.0 \%$ of the overlapped $\operatorname{lin}^{-} \mathrm{CD} 24^{\mathrm{mod}} \mathrm{CD} 29^{\text {high }}$ cells in puberty $(4 \mathrm{w}+1 \mathrm{~d})$ and pregnancy $(\mathrm{P} 5.5 \mathrm{~d})$, respectively. (C) in $^{-} \mathrm{CD} 24^{+} \mathrm{CD} 49 \mathrm{f}^{\text {high }} \mathrm{GFP}^{+}$ and $\operatorname{lin}^{-} \mathrm{CD} 24^{+} \mathrm{CD} 49 \mathrm{f}^{\text {high }} \mathrm{GFP}^{-}$cells were sorted from pubertal mammary glands of 5 -w + 1-d-old transgenic mice (shown in the dot plot), and were cultured in Matrigel or transplanted into cleared fat pads. The histogram shows the colony-forming capability of $\operatorname{lin}^{-} \mathrm{CD} 24^{+} \mathrm{CD} 49 \mathrm{f}^{\mathrm{high}} \mathrm{GFP}^{+}$cells is significantly higher than that of $\operatorname{lin}^{-} \mathrm{CD} 24^{+} \mathrm{CD} 49 \mathrm{f}^{\text {high }} \mathrm{GFP}^{-}$cells. Data represent mean $\pm \mathrm{SD}$ of five independent experiments. The table shows $\operatorname{lin}^{-} \mathrm{CD} 24^{+} \mathrm{CD} 49 \mathrm{f}^{\text {high }} \mathrm{GFP}^{+}$cells possess significantly higher regenerative potential than $\operatorname{lin}^{-} \mathrm{CD} 24^{+} \mathrm{CD} 49 \mathrm{f}^{\text {high }} \mathrm{GFP}^{-}$cells upon transplantation. The latter $\mathrm{GFP}^{-}$population may contain dormant MaSCs. 
Comparing our $\mathrm{GFP}^{+}$cells and $\operatorname{lin}^{-} \mathrm{CD} 24^{\text {mod }} \mathrm{CD} 49 \mathrm{f}^{\text {high }}$ or $\operatorname{lin}^{-} \mathrm{CD} 24^{\mathrm{mod}} \mathrm{CD} 29^{\text {high }}$ populations, we observed large differences in the distribution of cell populations between puberty, virgin, and pregnancy mammary cells. Regardless, although GFP was not present in the virgin mammary cells, $\mathrm{GFP}^{+}$cells exhibited a relatively consistent distribution, and represented $11 \%$ and $4 \%$ of the lin ${ }^{-} \mathrm{CD} 24^{\text {mod }} \mathrm{CD} 49 \mathrm{f}^{\text {high }}$ and lin ${ }^{-} \mathrm{CD} 24^{\mathrm{mod}} \mathrm{CD} 29^{\text {high }}$ populations, respectively (Fig. 5A,B).

These results demonstrate that the s-SHIP promoter expression-marked $\mathrm{GFP}^{+} \mathrm{MaSC}$ populations have properties similar to MaSCs defined in other laboratories. The single parameter isolation of activated MaSCs in puberty and pregnancy offers a facile one-step method for isolation of these cells, and, importantly, GFP expression enables identification of MaSCs in vivo.

\section{$G F P^{+}$cells in breast tumors}

We investigated GFP expression in different breast tumors from bitransgenic 11.5kb-GFP;MMTV-Wnt1 and 11.5kb-GFP;MMTV-ErbB2/neu/HER2 female mice. Wnt1 was reported to expand the MaSC-enriched population, and Wnt1-induced tumors consist of both myoepithelial and luminal cells (Li et al. 2003; Liu et al. 2004; Shackleton et al. 2006), whereas ErbB2 does not increase the number of MaSCs, and ErbB2-driven tumors contain primarily luminal cells (Li et al. 2003; Shackleton et al. 2006; Stingl and Caldas 2007). Our results showed that a large number $(8 \%-20 \%)$ of $\mathrm{GFP}^{+} \mathrm{SMA}^{+}$basal cells were detectable in Wnt1-inducted tumors (Fig. 6A,B). In contrast, ErbB2-induced tumors appeared devoid of $\mathrm{GFP}^{+}$ cells (Fig. 6C,D). The expansion of $\mathrm{GFP}^{+}$basal cells in Wnt 1 tumors supports previous results that Wnt1 specifically stimulates MaSCs growth (Li et al. 2003; Liu et al. 2004; Shackleton et al. 2006; Stingl and Caldas 2007), and illustrates the potential utility of the Tg11.5kb-GFP mouse model in addressing critical questions on the roles of MaSCs in mammary tumor formation.

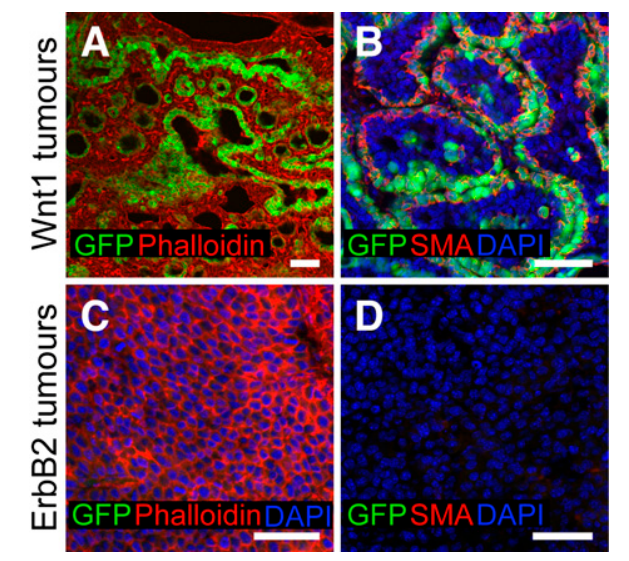

Figure 6. GFP expression in breast tumors. $(A, B)$ GFP is expressed in Wntl tumors $(A)$ and $\mathrm{GFP}^{+}$cells are $\mathrm{SMA}^{+}(B)$. $(C, D)$ No GFP expression was detected in ErbB2 tumors $(C)$, and no $\mathrm{SMA}^{+}$cells were detected in ErbB2 tumors $(D)$. Bars, $50 \mu \mathrm{m}$.

\section{Discussion}

Our data demonstrate that the cap cells at puberty and basal alveolar bud cells at early-midpregnancy are activated MaSCs that self-renew and contribute to all cell lineages of the mammary gland during development. GFP expression occurs in mammary buds at embryonic development (Rohrschneider et al. 2005), TEBs at puberty, and alveolar buds in pregnancy mammary glands of the Tg11.5kb-GFP mice, but not in mature cells of the mammary gland or at other developmental stages such as virgin, lactation, involution, and post-involution, in which MaSCs are relatively quiescent (Welm et al. 2002; Smith and Medina 2008). Therefore, we propose that $\mathrm{s}$-SHIP promoter expression labels the actively functioning MaSCs in the developing mammary gland, but not dormant MaSCs or differentiated cells. Our results suggest that MaSCs, dormant in prepubertal and virginal epithelial ducts, become activated when required for development in puberty and pregnancy. Dormant (i.e., $\mathrm{GFP}^{-}$| MaSCs are also present in puberty, probably along the completed portions of the epithelial ductwork, and in the pregnancy gland as well. Similar active (proliferating) stem cells have also been reported in the mouse intestine (Barker et al. 2007), the growth phase (anagen) of hair follicles (Blanpain et al. 2007; Jaks et al. 2008), and stimulated/injured bone marrow (Wilson et al. 2008).

Although transplantation is used routinely to identify MaSCs, it is not a quantitative assay due to technical limitations. Cell survival and functional activity of MaSCs may be compromised, owing to loss of cell viability caused by digestion and FACS-sorting stress (Vaillant et al. 2008), unavoidable cell loss during transplantation (Shackleton et al. 2006), and absence of the original stem cell niche. In addition, the $\mathrm{GFP}^{+}$cell population may contain some heterogeneity, composed of $\mathrm{GFP}^{+}$MaSCs and some relatively differentiated $\mathrm{GFP}^{+}$ progenitor cells, which may have recently turned off GFP expression but yet remain $\mathrm{GFP}^{+}$due to the long half-life of GFP (24 h). This suggests that the actual MaSC activity may be higher than observed by the results of transplantation.

An hierarchy of MaSCs comprised of ductal stem cells for puberty morphogenesis and alveolar stem/progenitor cells for lobulo-alveolar formation during pregnancy has been proposed (Smalley and Ashworth 2003; Hennighausen and Robinson 2005; Smith and Medina 2008). Our results, however, support the idea that MaSCs from different developmental stages have identical multipotential capabilities for producing all mammary cell types, including new MaSCs, committed progenitors (Smith 1996; Kordon and Smith 1998), and mature differentiated cells in puberty and pregnancy. For instance, $\mathrm{GFP}^{+}$alveolar bud cells, in the process of forming lobulo-alveoli, can switch to the pubertal developmental program and generate branched ductal networks along with TEBs when placed into pubertal fat pads (results in Fig. 4J,K). This suggests that MaSC fate determination is regulated by distinct niche/hormonal signals within each developmental stage, and is consistent with stromal cell signals providing 
instructive roles in mammary cell fate determination and morphogenesis during development (Hennighausen and Robinson 2001; Wiseman and Werb 2002). That mammary microenvironment reprograms testicular and neural stem cells also reflects the inductive function of niche signals (Boulanger et al. 2007; Booth et al. 2008). In addition, the niche is a critical factor in cancer development (Bissell and Labarge 2005). Thus, in both normal and aberrant development, the mammary niche/hormonal microenvironment plays a dominant role in lineage determination.

The isolation of adult stem cells in general-and MaSCs in particular-using multichannel flow cytometry is subject to variability from limited antibody specificity and technical variance (Alexander et al. 2009). In addition, the distribution of mammary tissue cells, based on cell surface marker expression, changes with the developmental phase (see Fig. 5A,B). Identification of MaSCs by GFP expression, however, is remarkably reproducible, and, although dormant MaSCs have not yet been detected in virgin ducts by GFP expression, we are working on methods to overcome this limitation. In addition, the coexpression of s-SHIP mRNA in activated $\mathrm{GFP}^{+} \mathrm{MaSC}$ suggests that s-SHIP may play a critical role in stem cell function. Therefore, isolation of MaSCs by GFP expression offers clear advantages of facile, reproducible isolation, along with the opportunity for functional analysis of s-SHIP in stem cells.

The Tg11.5kb-GFP mouse has enabled us to visualize the MaSCs and the compartments in which they reside. Basal-like human breast cancers are thought to develop from MaSCs (Yehiely et al. 2006; Stingl and Caldas 2007; Liu et al. 2008). Therefore, analyses of stem cells in mammary gland development and tumor formation in the Tg11.5kb-GFP mouse will provide significant insights into the regulatory mechanisms of MaSCs, and has major implications in developing new strategies to treat breast cancers.

\section{Materials and methods}

Mice

Tg11.5kb-GFP mice were backcrossed $>10$ generations onto a C57BL/6J background and genotyped by PCR (Rohrschneider et al. 2005). MMTV-Wnt1 mice were from Dr. C. Alexander, and MMTV-ErbB2 mice were from Dr. W. Muller. Animals were handled in accordance with the Guidelines for Animal Experiments at the Fred Hutchinson Cancer Research Center (FHCRC).

\section{Mammary cell preparation}

No. 3 and No. 4 mammary glands were dissected from 4- to 6-wk-old female mice for puberty, and P5.5-P8.5 at 10-24 wk of age for pregnancy experiments. The lymph node was removed from the No. 4 gland. Fresh tissue was minced to a paste with scissors and placed into culture medium (DMEM/F12 [Sigma] containing $1 \mathrm{mM}$ glutamine [GIBCO-BRL], $5 \mu \mathrm{g} / \mathrm{mL}$ insulin [Sigma], $1 \mu \mathrm{g} / \mathrm{mL}$ hydrocortisone [StemCell Technologies, Inc.], $10 \mathrm{ng} / \mathrm{mL}$ epidermal growth factor [Sigma], and $20 \mathrm{ng} / \mathrm{mL}$ cholera toxin [Sigma]) supplemented with $5 \%$ fetal bovine serum (FBS), and incubated with $300 \mathrm{U} / \mathrm{mL}$ collagenase IA (Sigma) and 100 $\mathrm{U} / \mathrm{mL}$ hyaluronidase (Sigma) for $1.5 \mathrm{~h}$ at $37^{\circ} \mathrm{C}$. The resultant cells/organoids were dissociated sequentially in $0.25 \%$ trypsinEDTA for 2-3 $\mathrm{min}$, and $5 \mathrm{mg} / \mathrm{mL}$ dispase (StemCell Technologies, Inc.) and $0.1 \mathrm{mg} / \mathrm{mL}$ DNase I (StemCell Technologies, Inc.) for $1 \mathrm{~min}$, then $4 \mathrm{vol} 0.8 \% \mathrm{NH}_{4} \mathrm{Cl}$ (StemCell Technologies, Inc.) was added for $3 \mathrm{~min}$, followed by filtration through a $40-\mu \mathrm{m}$ cell strainer. For serial transplantation of unsorted cells, the cells/ organoids of one lactating outgrowth were resuspended in $160 \mu \mathrm{L}$ of Hanks' Balanced Salt Solution (HBSS) with $2 \%$ FBS.

Flow cytometry, antibodies, and cell sorting

Single cells were preincubated with mouse Fc block-purified rat anti-CD16/CD32 Fc $\gamma$ III/II receptor antibody (1:50; BD Pharmingen) for $5 \mathrm{~min}$ at $4^{\circ} \mathrm{C}$, stained with antibodies for $20 \mathrm{~min}$ at $4^{\circ} \mathrm{C}$, washed, and resuspended in HBSS containing $10 \mathrm{mM} \mathrm{HEPES,} 2 \%$ FBS, and $1 \mu \mathrm{g} / \mathrm{mL}$ propidium iodide (PI) or $1 \mu \mathrm{g} / \mathrm{mL}$ DAPI before analysis. Antibodies used are as follows: PE-Cy5 rat anti-human CD49f (1:100; BD Pharmingen), PE rat anti-mouse CD24 (1:100; BD Pharmingen), PE-Cy7 rat anti-mouse CD24 (1:200; BD Pharmingen), PE Armenian hamster anti-mouse CD29 (1:200; BioLegend), APC Armenian hamster anti-mouse CD29 (1:100; eBioscience), PE rat anti-mouse Sca-1 (1:100; eBioscience), PE Armenian hamster anti-mouse CD61 (1:100; eBioscience), and PE rat anti-mouse prominin 1/CD133 (1:100; eBioscience); and lineage markers PE rat anti-mouse CD31 (1:100; eBioscience), PE rat anti-mouse CD45 (1:200; BD Pharmingen), PE rat anti-mouse TER-119 (1:200; eBioscience); and isotype control PE rat IgG (1:100; BD Pharmingen), PE Armenian hamster IgG (1:200; BioLegend), PE-Cy5 Rat IgG (1:100; BD Pharmingen), PE-Cy7 rat IgG2b (1:200; BD Pharmingen), and APC Armenian hamster IgG (1:100; eBioscience). The single live cells were gated and analyzed or sorted on FACSVantage or FACSAria flow cytometers. The purity of sorted populations was $\geq 95 \%$. Mammary cells from age-matched or pregnancy day-matched wild-type C57BL/6J mice were always collected and stained as control. Side population analysis was performed as described previously (Goodell et al. 1996).

\section{Cleared fat pad transplantation}

Cells were sorted into the wells of 96-well round-bottom ultralow binding plates (Nunc) containing HBSS with $2 \%$ FBS, recounted in $0.2 \%$ Trypan blue solution (Sigma), and diluted. The inguinal (No. 4) glands of 3-wk-old female C57BL/6J mice were cleared of endogenous epithelium as described previously (DeOme et al. 1959). Cells in $10 \mu \mathrm{L}$ of HBSS with $2 \%$ FBS were injected into each cleared fat pad.

\section{Single-cell transplantation}

Three-hundred microliters of cell suspension $\left(1 \times 10^{2}\right.$ cells per milliliter) was placed in a $10-\mathrm{cm}$ bacterial dish, spread to an $\sim 3.0$-cm-diameter area, and set on ice with the dish covered for $\geq 40 \mathrm{~min}$ to let cells settle down. Using a dissection microscopy, single sorted cells were identified and picked using Micro Pipettes (Fisher), and injected. In control experiments, one cell in each drop of the Micro Pipettes was confirmed in 50 out of 50 cases.

\section{Transplantation analysis}

Recipient glands were collected at 5-10 wk after surgery, and at $\geq 12$ wk after transplantation of 10 or fewer cells. Most recipients were mated to induce lobulo-alveolar development. A positive outgrowth was defined as a complete epithelial structure containing ducts radiating from the central injection 
site with elaborated branches and/or TEBs (at puberty) or lobuloalveoli (at pregnancy and lactation). Outgrowths were detected by GFP expression and carmine alum whole-mount (Rasmussen et al. 2000) or X-gal staining. Frozen sections were analyzed by immunostaining or X-gal staining.

\section{Matrigel cell culture}

Cells were resuspended in 100\% Matrigel (Becton Dickinson), and a $50-\mu \mathrm{L}$ suspension of Matrigel per cells was placed into each well of eight-well coverslip bottom chambers (Nunc) and allowed to settle for $20 \mathrm{~min}$ at $37^{\circ} \mathrm{C}$ before covering with culture medium supplemented with $5 \%$ FBS. After $48 \mathrm{~h}$, the medium was changed to DMEM/F12 containing $1 \mathrm{mg} / \mathrm{mL}$ fatty acid-free bovine serum albumin (BSA) (Sigma), $5 \mu \mathrm{g} / \mathrm{mL}$ insulin, $5 \mu \mathrm{g} / \mathrm{mL}$ prolactin (Sigma), $1 \mu \mathrm{g} / \mathrm{mL}$ progesterone (Sigma), $1 \mu \mathrm{g} / \mathrm{mL}$ hydrocortisone, and $10 \mathrm{ng} / \mathrm{mL}$ epidermal growth factor. Cells were cultured for another $10 \mathrm{~d}$, and then fixed in $4 \%$ paraformaldehyde and stained with antibodies as described (Debnath et al. 2003).

\section{BrdU incorporation}

Mice were injected i.p. with $100 \mu \mathrm{g} / \mathrm{g}$ BrdU (Sigma) $4 \mathrm{~h}$ prior to sample collection (Barker et al. 2007).

\section{Immunofluorescence and antibodies}

Tissues were fixed in $2 \%$ paraformaldehyde for $4 \mathrm{~h}$, put into $30 \%$ sucrose overnight, embedded in O.C.T., frozen on dry ice, and cut into $14-\mu \mathrm{m}$ sections. Tissue sections were permeabilized with $0.5 \%$ Triton X-100, blocked with $5 \%$ FBS, and then incubated sequentially with primary antibodies for $45 \mathrm{~min}$ at room temperature, and with secondary antibodies for $45 \mathrm{~min}$ at room temperature. Slides were washed three times in phosphatebuffered saline (PBS) after each antibody incubation, and sections were mounted in Prolong Gold (Invitrogen). For BrdU staining, sections were treated with $2 \mathrm{~N} \mathrm{HCl}$ for $30 \mathrm{~min}$ to denature DNA before permeabilization. M.O.M kit (Vector) was used for detecting mouse primary antibodies. Primary antibodies used for this study were Alexa Fluor 488-conjugated rabbit anti-GFP (1:800; Invitrogen), Alexa Fluor 594 phalloidin (1:100; Molecular Probes), Alexa Fluor 488 phalloidin (1:100; Molecular Probes), mouse monoclonal anti-p63 (1:100; Santa Cruz Biotechnology), mouse monoclonal Cy3-conjugated anti- $\alpha$-SMA (1:800; Sigma), rabbit anti-laminin general (1:10,000; a kind gift of Dr. William Carter), rabbit anti-mouse K14 (1:1000; Covance), affinity-purified rat anti-human/mouse integrin $\alpha 6$ (1:100; eBioscience), rabbit polyclonal anti-Ki67 (1:400; Abcam), Alexa Fluor 594conjugated mouse anti-BrdU (1:400; Molecular Probes), rat antiE-cad (1:200; Zymed), rabbit polyclonal anti-human PR (1:100; DakoCytomation), and rabbit polyclonal antiserum to mouse milk-specific proteins (1:400; Nordic Immunological Laboratories). Fluorochrome-conjugated secondary antibodies included Alexa Fluor 594-conjugated goat anti-rabbit IgG, Alexa Fluor 488-conjugated goat anti-rabbit IgG, Alexa Fluor 594-conjugated goat anti-rat IgG, Alexa Fluor 488-conjugated goat anti-rat IgG, and Alexa Fluor 594-conjugated goat anti-mouse IgG (all 1:1000; Molecular Probes). Sections were counterstained with DAPI (1 $\mu \mathrm{g} / \mathrm{mL}$; Sigma). Pictures were taken on a Zeiss LSM 510 META Confocal Microscope (Carl Zeiss MicroImaging, Inc.)

\section{X-gal staining}

Whole-mount mammary tissue was fixed in $2 \%$ formaldehyde, $0.25 \%$ glutaraldehyde, and $0.01 \%$ Nonidet $\mathrm{P}-40$ for $1 \mathrm{~h}$ at $4{ }^{\circ} \mathrm{C}$, stained with $1 \mathrm{mg} / \mathrm{mL} \mathrm{X-gal} \mathrm{overnight} \mathrm{at} 37^{\circ} \mathrm{C}$ for outgrowth of lac $Z^{+}$cell transplantation, then dehydrated and cleared in xylene before imaging. Frozen sections from fixed tissues were stained with X-gal and counterstained with nuclear fast red.

\section{RT-PCR analyses}

RT-PCR was performed using gene-specific primers with the One-Step RT-PCR kit (Qiagen) according to the manufacturer's instructions with some modifications. Twenty cells were sorted into the well of a 96-well low-binding plate containing $20 \mu \mathrm{L}$ of RNA sample buffer $(0.5 \%$ Nonidet P- $40,1 \times$ one-step RT buffer, $1 \mathrm{U} / \mu \mathrm{L}$ RNase inhibitor in RNase free $\mathrm{H}_{2} \mathrm{O}$ ). Eight microliters of RNA sample was used for s-SHIP gene amplification, and $2 \mu \mathrm{L}$ of RNA sample was used for GAPDH. A second round of PCR was performed with the same primers of each gene using the first round of PCR product as a template, $6 \mu \mathrm{L}$ for s-SHIP, and $0.5 \mu \mathrm{L}$ for GAPDH, respectively. Primer sequences were as follows: s-SHIP forward, 5'-GTTCCCACTAGTTGTTGAACTTTAC CTT-3'; s-SHIP reverse, 5' -CAACGTCCACTTTGAGATGCAT-3'; GAPDH forward, 5'-AAGGTCATCCCAGAGCTGAACGG-3'; GAPDH reverse, 5'-TGAGGGAGATGCAGTGTTGGG-3'. All primers spanned more than one intron, and positive and negative control amplifications were performed in parallel to ensure no contaminating genomic DNA was present.

\section{Statistics}

MaSC frequency was calculated using a complementary log-log binomial generalized linear model with $95 \%$ confidence intervals, using limdil software as described previously (Shackleton et al. 2006; Quintana et al. 2008). The $P$-value was determined by likelihood ratio test. The single-hit assumption was tested with standard $\chi^{2}$ statistics, and was not rejected for any dilution series $(P>0.05)$. Colony-forming capability in Matrigel was compared with two-tailed Student's $t$-test.

\section{Acknowledgments}

We thank C. Alexander for the MMTV-Wnt1 mice, W. Miller for the MMTV-ErbB2 mice, William Carter for the laminin general antibody, and Cecelia Moens and Bruce Edgar for use of their confocal microscope and assorted digital microscopes, respectively. Members of the Rohrschneider laboratory offered valuable discussions, and the Shared Resources at the Center (Image Analysis, Flow Cytometry, Animal Health Resources) provided essential, expert, and helpful assistance throughout this project. We thank Yan Liu (FHCRC) for the statistics assistance. We give special thanks to Mark Shackleton, Bryan Welm, and Matthew Smalley for helpful advice. We thank Roland Bourette, Jim Roberts, and Jon Cooper for critical review and helpful suggestions on the manuscript. This work was supported by interim funds from the FHCRC, NIH/NCI grants R56 CA123360 and R01 CA40987, and financial support from anonymous donors.

\section{References}

Alexander CM, Puchalski J, Klos KS, Badders N, Ailles L, Kim CF, Dirks P, Smalley MJ. 2009. Separating stem cells by flow cytometry: Reducing variability for solid tissues. Cell Stem Cell 5: 579-583.

Asselin-Labat ML, Shackleton M, Stingl J, Vaillant F, Forrest NC, Eaves CJ, Visvader JE, Lindeman GJ. 2006. Steroid hormone receptor status of mouse mammary stem cells. J Natl Cancer Inst 98: 1011-1014. 
Asselin-Labat ML, Sutherland KD, Barker H, Thomas R, Shackleton M, Forrest NC, Hartley L, Robb L, Grosveld FG, van der Wees J, et al. 2007. Gata-3 is an essential regulator of mammary-gland morphogenesis and luminalcell differentiation. Nat Cell Biol 9: 201-209.

Barker $\mathrm{N}$, van Es JH, Kuipers J, Kujala $\mathrm{P}$, van den Born $\mathrm{M}$, Cozijnsen M, Haegebarth A, Korving J, Begthel H, Peters PJ, et al. 2007. Identification of stem cells in small intestine and colon by marker gene Lgr5. Nature 449: 1003-1007.

Bissell MJ, Labarge MA. 2005. Context, tissue plasticity, and cancer: Are tumor stem cells also regulated by the microenvironment? Cancer Cell 7: 17-23.

Blanpain C, Horsley V, Fuchs E. 2007. Epithelial stem cells: Turning over new leaves. Cell 128: 445-458.

Booth BW, Mack DL, Androutsellis-Theotokis A, McKay RD, Boulanger CA, Smith GH. 2008. The mammary microenvironment alters the differentiation repertoire of neural stem cells. Proc Natl Acad Sci 105: 14891-14896.

Boulanger CA, Mack DL, Booth BW, Smith GH. 2007. Interaction with the mammary microenvironment redirects spermatogenic cell fate in vivo. Proc Natl Acad Sci 104: 3871-3876.

Daniel CW, Silberstein GB. 2000. Working with the mouse mammary end bud. In Methods in mammary gland biology and breast cancer research (ed. MM Ip, BB Asch), pp. 155162. Kluwer Academic/Plenum, New York.

Daniel CW, DeOme KB, Young JT, Blair PB, Faulkin LJ Jr. 1968. The in vivo life span of normal and preneoplastic mouse mammary glands: A serial transplantation study. Proc Natl Acad Sci 61: 53-60.

Debnath J, Muthuswamy SK, Brugge JS. 2003. Morphogenesis and oncogenesis of MCF-10A mammary epithelial acini grown in three-dimensional basement membrane cultures. Methods 30: 256-268.

DeOme KB, Faulkin LJ Jr, Bern HA, Blair PB. 1959. Development of mammary tumors from hyperplastic alveolar nodules transplanted into gland-free mammary fat pads of female C3H mice. Cancer Res 19: 515-520.

Deugnier MA, Faraldo MM, Teuliere J, Thiery JP, Medina D, Glukhova MA. 2006. Isolation of mouse mammary epithelial progenitor cells with basal characteristics from the CommaD $\beta$ cell line. Dev Biol 293: 414-425.

Friedrich G, Soriano P. 1991. Promoter traps in embryonic stem cells: A genetic screen to identify and mutate developmental genes in mice. Genes Dev 5: 1513-1523.

Goodell MA, Brose K, Paradis G, Conner AS, Mulligan RC. 1996. Isolation and functional properties of murine hematopoietic stem cells that are replicating in vivo. J Exp Med 183: 1797-1806.

Hennighausen L, Robinson GW. 2001. Signaling pathways in mammary gland development. Dev Cell 1: 467-475.

Hennighausen L, Robinson GW. 2005. Information networks in the mammary gland. Nat Rev Mol Cell Biol 6: 715-725.

Iwashita T, Kruger GM, Pardal R, Kiel MJ, Morrison SJ. 2003. Hirschsprung disease is linked to defects in neural crest stem cell function. Science 301: 972-976.

Jaks V, Barker N, Kasper M, van Es JH, Snippert HJ, Clevers H, Toftgard R. 2008. Lgr5 marks cycling, yet long-lived, hair follicle stem cells. Nat Genet 40: 1291-1299.

Jones PH, Harper S, Watt FM. 1995. Stem cell patterning and fate in human epidermis. Cell 80: 83-93.

Kordon EC, Smith GH. 1998. An entire functional mammary gland may comprise the progeny from a single cell. Development 125: 1921-1930.

Lawson DA, Xin L, Lukacs RU, Cheng D, Witte ON. 2007. Isolation and functional characterization of murine prostate stem cells. Proc Natl Acad Sci 104: 181-186.
Li Y, Welm B, Podsypanina K, Huang S, Chamorro M, Zhang X, Rowlands T, Egeblad M, Cowin P, Werb Z, et al. 2003. Evidence that transgenes encoding components of the Wnt signaling pathway preferentially induce mammary cancers from progenitor cells. Proc Natl Acad Sci 100: 1585315858.

Lindeman GJ, Visvader JE, Smalley MJ, Eaves CJ. 2008. The future of mammary stem cell biology: The power of in vivo transplants. Breast Cancer Res 10: 402. doi: 10.1186/bcr.1986.

Liu BY, McDermott SP, Khwaja SS, Alexander CM. 2004. The transforming activity of Wnt effectors correlates with their ability to induce the accumulation of mammary progenitor cells. Proc Natl Acad Sci 101: 4158-4163.

Liu S, Ginestier C, Charafe-Jauffret E, Foco H, Kleer CG, Merajver SD, Dontu G, Wicha MS. 2008. BRCA1 regulates human mammary stem/progenitor cell fate. Proc Natl Acad Sci 105: 1680-1685.

Mills AA, Zheng B, Wang XJ, Vogel H, Roop DR, Bradley A. 1999. p63 is a p53 homologue required for limb and epidermal morphogenesis. Nature 398: 708-713.

Quintana E, Shackleton M, Sabel MS, Fullen DR, Johnson TM, Morrison SJ. 2008. Efficient tumour formation by single human melanoma cells. Nature 456: 593-598.

Rasmussen SB, Young LJ, Smith GH. 2000. Preparing mammary gland whole mounts from mice. In Methods in mammary gland biology and breast cancer research (ed. MM Ip, BB Asch), pp. 82-83. Kluwer Academic/Plenum, New York.

Rohrschneider LR, Custodio JM, Anderson TA, Miller CP, Gu H. 2005. The intron $5 / 6$ promoter region of the shipl gene regulates expression in stem/progenitor cells of the mouse embryo. Dev Biol 283: 503-521.

Senoo M, Pinto F, Crum CP, McKeon F. 2007. p63 Is essential for the proliferative potential of stem cells in stratified epithelia. Cell 129: 523-536.

Shackleton M, Vaillant F, Simpson KJ, Stingl J, Smyth GK, Asselin-Labat ML, Wu L, Lindeman GJ, Visvader JE. 2006. Generation of a functional mammary gland from a single stem cell. Nature 439: 84-88.

Singh SK, Hawkins C, Clarke ID, Squire JA, Bayani J, Hide T, Henkelman RM, Cusimano MD, Dirks PB. 2004. Identification of human brain tumour initiating cells. Nature 432: 396-401.

Sleeman KE, Kendrick H, Ashworth A, Isacke CM, Smalley MJ. 2006. CD24 staining of mouse mammary gland cells defines luminal epithelial, myoepithelial/basal and non-epithelial cells. Breast Cancer Res 8: R7. doi: 10.1186/bcr1371.

Sleeman KE, Kendrick H, Robertson D, Isacke CM, Ashworth A, Smalley MJ. 2007. Dissociation of estrogen receptor expression and in vivo stem cell activity in the mammary gland. J Cell Biol 176: 19-26.

Smalley M, Ashworth A. 2003. Stem cells and breast cancer: A field in transit. Nat Rev Cancer 3: 832-844.

Smith GH. 1996. Experimental mammary epithelial morphogenesis in an in vivo model: Evidence for distinct cellular progenitors of the ductal and lobular phenotype. Breast Cancer Res Treat 39: 21-31.

Smith GH, Medina D. 2008. Re-evaluation of mammary stem cell biology based on in vivo transplantation. Breast Cancer Res 10: 203.

Srinivasan K, Strickland P, Valdes A, Shin GC, Hinck L. 2003. Netrin-1/neogenin interaction stabilizes multipotent progenitor cap cells during mammary gland morphogenesis. Dev Cell 4: 371-382.

Stingl J, Caldas C. 2007. Molecular heterogeneity of breast carcinomas and the cancer stem cell hypothesis. Nat Rev Cancer 7: 791-799. 
Stingl J, Eirew P, Ricketson I, Shackleton M, Vaillant F, Choi D, Li HI, Eaves CJ. 2006. Purification and unique properties of mammary epithelial stem cells. Nature 439: 993-997.

Tu Z, Ninos JM, Ma Z, Wang JW, Lemos MP, Desponts C, Ghansah T, Howson JM, Kerr WG. 2001. Embryonic and hematopoietic stem cells express a novel SH2-containing inositol 5'-phosphatase isoform that partners with the Grb2 adapter protein. Blood 98: 2028-2038.

Vaillant F, Asselin-Labat ML, Shackleton M, Forrest NC, Lindeman GJ, Visvader JE. 2008. The mammary progenitor marker CD61/ß3 integrin identifies cancer stem cells in mouse models of mammary tumorigenesis. Cancer Res 68: 7711-7717.

Welm BE, Tepera SB, Venezia T, Graubert TA, Rosen JM, Goodell MA. 2002. Sca-1(pos) cells in the mouse mammary gland represent an enriched progenitor cell population. Dev Biol 245: 42-56.

Williams JM, Daniel CW. 1983. Mammary ductal elongation: Differentiation of myoepithelium and basal lamina during branching morphogenesis. Dev Biol 97: 274-290.

Wilson A, Laurenti E, Oser G, van der Wath RC, Blanco-Bose W, Jaworski M, Offner S, Dunant CF, Eshkind L, Bockamp E, et al. 2008. Hematopoietic stem cells reversibly switch from dormancy to self-renewal during homeostasis and repair. Cell 135: 1118-1129.

Wiseman BS, Werb Z. 2002. Stromal effects on mammary gland development and breast cancer. Science 296: 1046-1049.

Yang A, Schweitzer R, Sun D, Kaghad M, Walker N, Bronson RT, Tabin C, Sharpe A, Caput D, Crum C, et al. 1999. p63 is essential for regenerative proliferation in limb, craniofacial and epithelial development. Nature 398: 714-718.

Yehiely F, Moyano JV, Evans JR, Nielsen TO, Cryns VL. 2006. Deconstructing the molecular portrait of basal-like breast cancer. Trends Mol Med 12: 537-544.

Zhu L, Gibson P, Currle DS, Tong Y, Richardson RJ, Bayazitov IT, Poppleton H, Zakharenko S, Ellison DW, Gilbertson RJ. 2009. Prominin 1 marks intestinal stem cells that are susceptible to neoplastic transformation. Nature 457: 603607. 


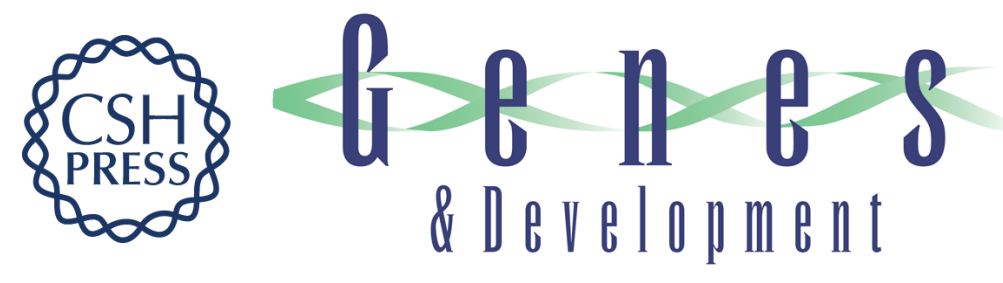

\section{s-SHIP promoter expression marks activated stem cells in developing mouse mammary tissue}

Lixia Bai and Larry R. Rohrschneider

Genes Dev. 2010, 24:

Access the most recent version at doi:10.1101/gad.1932810

Supplemental
Material http://genesdev.cshlp.org/content/suppl/2010/08/30/24.17.1882.DC1

References This article cites 48 articles, 16 of which can be accessed free at: http://genesdev.cshlp.org/content/24/17/1882.full.html\#ref-list-1

License

Email Alerting Receive free email alerts when new articles cite this article - sign up in the box at the top Service right corner of the article or click here.

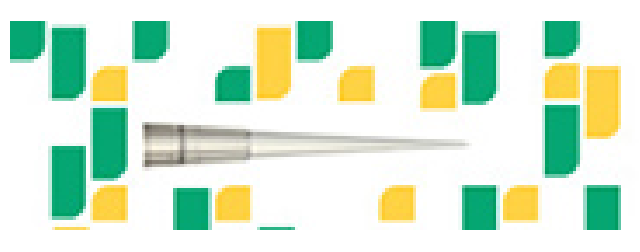

Focused on your science. 